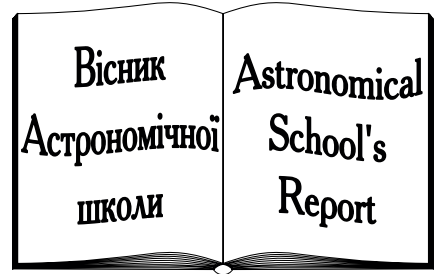

ISSN 2411-6602 (Online)

ISSN 1607-2855 (Print)

Volume $16 \bullet$ Issue $1 \bullet 2020 \quad$ P. $8-15$

https://doi.org/10.18372/2411-6602.16.02

UDC 523.68

\title{
The physics of space intrusions. I. Features of the trajectories
}

\section{B.E. Zhilyaev, A.P. Vidmachenko*, A.F.Steklov, S.M. Pokhvala, I.A. Verlyuk}

The Main Astronomical Observatory of the NAS of Ukraine, 03143, Academician Zabolotny str., 27, Kyiv, Ukraine

This paper presents theoretical developments of some issues in the physics of space intrusions. We report the discovery of a new effect - variations in brightness and "wobbling" in the meteor trail. The frequency of the variations of brightness $\left(f_{c}\right)$ and wobbling $\left(f_{m}\right)$ that can be measured is important information parameters that allow us to obtain estimates all the characteristics of the meteor if its height and speed are known. Basic two-side intrusion observations automatically determine both the height and speed of the intrusion. We offer a new "tuning technique" that allows determining the meteor characteristics during one-side observations. The essence of a new technique is to fine-tune the initial parameters of the simulation model of intrusion until the calculated and measured frequencies $f_{c}$, $f_{m}$ coincide. We found that rotation plays an important role in the dynamics of meteors; in particular, they can burst in due to centrifugal forces that exceed the strength of the material. In the case of one-side observations, we construct a grid of intrusion models using the Impact 4 A software program on the plane of the primary "mass-speed" meteoroid. As a result of modelling, we find the height at which the frequency ratio $f_{c} / f_{m}$ coincides with the value found from measurements for exploding meteoroid. The paper describes the characteristics of the space intrusion of a meteor in Kyiv on August 12, 2019, 22:52:57 UT. The amplitude of the brightness fluctuations was found about 0.1 magnitudes, the amplitude of the wobbling of about 4 arc seconds. Using the Impact $4 A$ software program the preatmospheric velocity was evaluated $\sim 40 \mathrm{~km} / \mathrm{sec}$; the mass of the meteoroid was evaluated approximately $0.45 \mathrm{~kg}$. This meteoroid reached maximum light at $82.2 \mathrm{~km}$ and ablated partially. We find estimates of a residual mass of about 10 grams and a residual speed of about $20 \mathrm{~km} / \mathrm{s}$. We found that the radius of the helical path of the meteor at this height is about 1.5 meters. The meteoroid reached a critical value of the speed of rotation on the surface. At this moment, a meteoroid exploded and destroyed.

Keywords: space intrusions; methods: observational; processing techniques: photometric; objects: meteors.

\section{INTRODUCTION}

The physical theory of meteors appeared about 100 years ago [1,2]. Already in the 1930s, about 5,500 published meteor ignition heights were known based on two-point observations. On average, ignition was observed at an altitude of $115 \mathrm{~km}$, and attenuation at an altitude of $80 \mathrm{~km}$. Based on these data, Lindermann and Dobson [2] developed the first rigorous physical theory of meteors. In theory, there were seven independent quantities through which it was necessary to find the heights of ignition of meteors, radiation energy, temperature. The speed, size, and chemical composition of meteors remained unknown parameters. This made physical theory incomplete. It should be noted that the task, in general, remains unsolved to this day.

Last time the computer program has developed for estimating the environmental consequences of a comet or asteroid impact on Earth. The program requires six inputs: impactor diameter, impactor density, impact velocity before atmospheric entry, impact angle, and the target type (sedimentary rock, crystalline rock) $[3,12]$.

The motion of a meteoroid through the atmosphere in 3D simulations was performed by set of authors [4, 5]. The following results were obtained. On average, objects travelling at initial speeds of $10 \mathrm{~km} / \mathrm{s}$ all reach the surface with $\sim 50 \%$ of their mass so long as they are at least $0.05 \mathrm{~kg}$ before entering the atmosphere. Objects travelling at speeds of $14 \mathrm{~km} / \mathrm{s}$ impact the surface with $\sim 25 \%$ of their initial mass. Meteors with initial velocities of $18 \mathrm{~km} / \mathrm{s}$ reach the surface with only $11-17 \%$ of their initial mass. If the initial velocity is $22 \mathrm{~km} / \mathrm{s}$, objects are subjected to more heating, thus more readily ablate and reach the surface with $3-5 \%$ of their initial mass. As the initial velocity increases, a meteor is subjected to even more ablation. Meteors with initial velocities between 26 to $38 \mathrm{~km} / \mathrm{s}$ reach the surface with only 0.9 to $0.0001 \%$ of their starting mass.

On August 12, 2019 a meteoroid of about -2 magnitudes was observed radiating from the square of Perseus. The fireball was recorded by a camera equipped by the diffraction grating. One spectrum has been obtained. It was found a meteoroid to be of the stone composition. This fireball is thought to come from the outer portions of the comet nucleus.

Below we consider the results of observations, focusing on the theoretical analysis of the temporal features of the meteoroid trajectories. We also estimate the main parameters of intrusion based on the model

*Vidmachenko Anatoliy Petrovych; $\square$ vida@mao.kiev.ua

8 Zhilyaev B.E., Vidmachenko A.P., Steklov A.F., Pokhvala S.M., Verlyuk I.A. 
of the ablation for estimation the meteoroid characteristics. We also compare the results of the theory and observations and present results and conclusions.

\section{OBSERVATIONS}

This work is based on the analysis of meteor spectra with low dispersion grism spectrograph obtained on August 12, 2019, 22:52:57 UT at the Main Astronomical Observatory of the NAS of Ukraine. The ZWO ASI 174 camera used was provided with Computar objective having focal lengths of $8 \mathrm{~mm}$. The camera was equipped with a transmission objective grating with 100 grooves per millimeter.

Frame calibration was performed to take into account bias current, dark current and flat field. Precise photometry requires at least one reference star in each image. Such a star can be seen in Fig. 1 (Polaris, $\alpha \mathrm{UMi}$, bottom of the frame) with a known intensity distribution in the spectrum. This allows us to calibrate the intensity of the spectral lines of the meteor in absolute units.

Meteoroids entering the Earth's atmosphere form a plasma track. The creation of the plasma is described by the meteor ablation theory developed by McKinley [6] and Ceplecha et al. [7]. A spectrophotometric analysis of a meteor of about -2 visual magnitude is presented on the basis of spectrogram with absolute intensities of the lines.

The spectrum of a meteor is shown in Fig. 1. A meteoroid was found to be of the stone composition. The zero-order spectrum along the meteor track is shown in Fig. 2. The zero-order spectrum is an optical replica of a meteor track. The fireball had a triple terminal burst with a duration of about 0.3 seconds with a $3.0-$ second train. It shows clearly oscillations of brightness.

Below we offer a new "tuning technique" that allows determining the meteor characteristics during one-side observations.

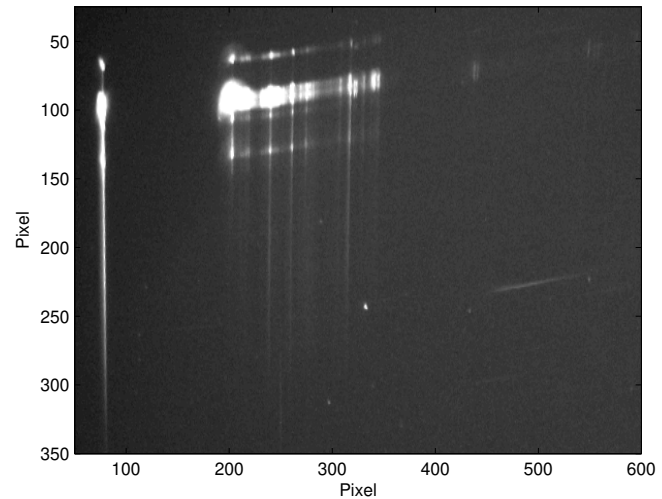

Fig. 1. The meteor spectrum of about -2 visual magnitude. A meteoroid was found to be of the stone composition. The Polaris spectrum, $\alpha \mathrm{UMi}$, can be seen at the bottom of the frame

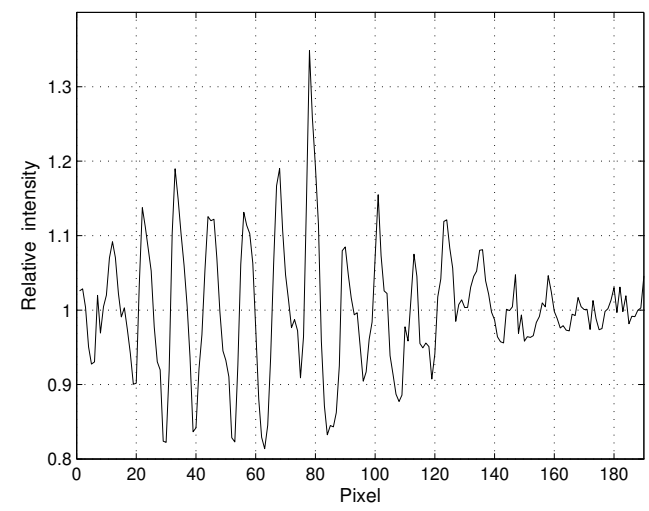

Fig. 3. Brightness variations with time along the meteor track

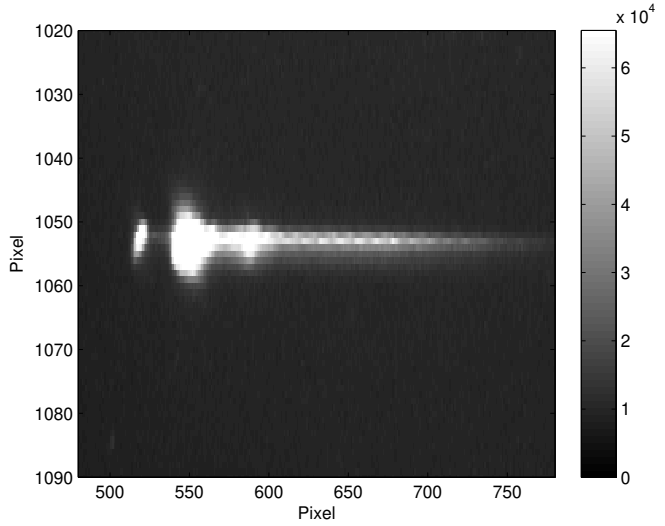

Fig. 2. The zero order spectrum along the meteor track shows oscillations of brightness. The fireball had a triple terminal burst with a duration of about 0.3 seconds with a 3.0 - second train.

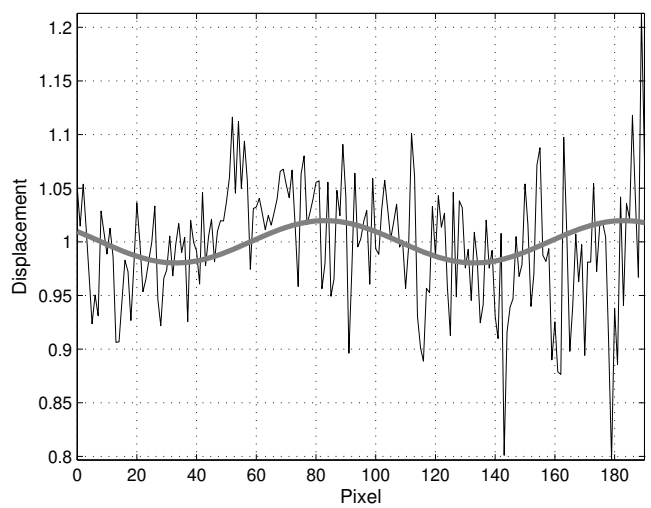

Fig. 4. Oscillation in the trajectory transverse to the direction of motion

\section{ANALYSIS OF THE TEMPORAL FEATURES OF THE METEOROID TRAIL}

It is well known that a swirling ball flies along a curved path. Deviations from rectilinear motion indicate the presence of strength perpendicular to the direction of the flight path. This phenomenon is known as the 
Magnus effect. It occurs when a stream of gas flows around a rotating body. The Magnus lifting force $F_{m}$ occurs when a body of arbitrary shape rotates. The simplest expression is known for a cylindrical body [8]

$$
\overrightarrow{\mathbf{F}}_{m}=2 S \rho r_{m}\left[\overrightarrow{\mathbf{v}} \times \overrightarrow{\boldsymbol{\omega}}_{m}\right]
$$

where $S=\pi r_{m} L_{m}$ is an area of a cylinder, $r_{m}$ and $L_{m}$ are the radius and length of the cylinder, $\rho-$ gas density, $v-$ flow velocity at infinity, $\omega_{m}$ is the frequency of angular rotation.

We have not the knowledge of shape and size in the case of a meteoroid. The effective cross-section of the body $S$ in the direction of travel is an important parameter in the deceleration process. For a meteoroid it is conventional to define a dimensionless shape parameter $A$ where

$$
S=A\left(m / \rho_{m}\right)^{2 / 3} .
$$

The values of $A$ for sphere is $A=1.2$, for cylinder and cube $1.0<A<1.7$ [12].

The equation of motion of a meteoroid of mass $m$ and velocity $v$ is written in the form

$$
m \overrightarrow{\dot{v}}=\overrightarrow{\mathbf{F}}_{c}+\overrightarrow{\mathbf{F}}_{m} .
$$

The aerodynamic drag force $F_{c}$ is comparable to the Magnus force $F_{m}$ acting on the meteoroid:

$$
F_{c}=\frac{1}{2} C_{D} \cdot \rho \cdot v^{2} \cdot \pi r_{m}^{2}
$$

where $C_{D}$ is the drag coefficient depends on the shape of the body. The measured drag coefficient $C_{D}$ for spheres versus the Mach number varies across the subsonic, supersonic, and hypersonic regimes. For a ball, its value in the subsonic range is of $0.1-0.4$. The large drag rise in the subsonic regime associated with the drag-divergence phenomenon near Mach 1 and the decrease in $C_{D}$ in the supersonic regime. Beyond Mach $1 C_{D}$ approaches a plateau $\left(C_{D} \simeq 1\right)$ and becomes relatively independent of the Mach number as $M$ becomes large [9].

Formally, formulas (1)-(4) allow us to calculate the trajectory of a meteoroid under the action of drag and Magnus's lifting forces. We take into account that the meteoroid moves in the atmosphere, where the air density $\rho$ varies with altitude. The dynamical properties of oscillations can be studied under the assumption that within some distance along the meteoroid trace we can approximate the density variation in the form

$$
\rho(z)=\rho_{0}-\frac{d \rho}{d z} z
$$

and introduce parameter $H_{\rho}=\rho /(d \rho / d z)$ - the height of the homogeneous atmosphere, approximately $7 \mathrm{~km}$. It can be shown that the error approximation of density variations in the form (5) within $H_{\rho}$ does not exceed $5 \%$.

The equation of motion (3) of the meteoroid along the transverse coordinates $x, y$ in this approximation is written in the form

$$
\dot{\overrightarrow{\mathbf{v}}}=\left(v_{x} \overrightarrow{\mathbf{j}}-v_{y} \overrightarrow{\mathbf{i}}\right) \cdot \frac{3}{2} \frac{\rho \omega_{m}}{\rho_{m}} \cdot \sin \theta \cdot\left(1+\frac{z}{H_{\rho}}\right),
$$

where $\rho_{m}-$ meteoroid density, $z$ is coordinate along the meteoroid track, $\theta$ is the zenith angle. Equations of motion of meteoroid in plane polar coordinates $r, \varphi$ perpendicular coordinate $z$ have the form

$$
x=R \cdot \cos \left(\Theta_{m} t+\varphi_{0}\right), \quad y=R \cdot \sin \left(\Theta_{m} t+\varphi_{0}\right)
$$

where $R$ is the radius of the helical path. The main frequency of rotation of Magnus $\Theta_{m}$ has the form

$$
\Theta_{m}=2 \pi f_{m}=\frac{3}{2} \frac{\rho \omega_{m}}{\rho_{m}} \cdot \sin \theta \cdot\left(1+\frac{z}{H_{\rho}}\right) .
$$

In the linear approximation, we can neglect variations of $v$ within $H_{\rho}$ along the meteoroid track. In this approximation the equation of motion of a meteoroid for the $z$ coordinate is written in the form of an inhomogeneous differential equation of the second degree

where the coefficients $A$ and $B$ have the form

$$
\ddot{z}-A \cdot z=B,
$$

$$
A=\frac{3}{4} \frac{C_{D} \rho v^{2} \sin \theta}{r_{m} \rho_{m} H_{\rho}}, \quad B=\frac{3}{4} \frac{C_{D} \rho v^{2} \sin \theta}{r_{m} \rho_{m}} .
$$

Here $\rho$ and $\rho_{m}$ are the densities of air and meteoroid, respectively. The oscillation solution of the inhomogeneous differential equation of the second degree is written in the form

$$
z=a \cdot \cos \left(\Theta_{c} t+\varphi_{0}\right)+H_{\rho},
$$

where $a$ and $\varphi$ are the amplitude and phase, and the angular frequency of the brightness variations of the meteoroid $\Theta_{c}$ has the form:

$$
\Theta_{c}=2 \pi f_{c}=\sqrt{A}=\sqrt{\frac{3}{4} \frac{C_{D} \rho v^{2} \sin \theta}{r_{m} \rho_{m} H_{\rho}}} .
$$

The amplitude of the oscillation cannot be predicted by the linear theory. 10 Zhilyaev B.E., Vidmachenko A.P., Steklov A.F., Pokhvala S.M., Verlyuk I.A. 
Note that the "wobbling" and fluctuations in the brightness of the meteoroid on the flight path are not described in the literature; in any case, the theory of this phenomenon is absent.

Of particular note is the fluctuation in the brightness of the meteoroid. Equation (8) is a typical case of the oscillator equation. For oscillation to occur, a restoring force must exist. In our case, it is related to the gradient of the atmospheric density. The explanation of the fluctuations is easy to understand with a simplified example. Imagine that the density does not change continuously but in the form of steps. Each step during the movement of the meteoroid provokes a blow, which can cause oscillations. It is easy to see that in an homogeneous atmosphere $(\sin \theta=0)$, brightness fluctuations will be absent.

What causes meteor brightness fluctuations? Variations in the $z$ coordinate and meteoroid velocity due to uneven motion modulate its brightness according to equation (11).

The characteristic features of the problem can be understood from the local analysis based on equations (7), (12). These equations for oscillation frequencies contain four unknown quantities: $\rho, \omega_{m}, r_{m}, v-$ the density, rotation frequency, meteoroid size, and speed. Basic two-side intrusion observations automatically determine the height and therefore $\rho$ as well as speed $v$ of the intrusion. And then, equations (7), (12) allow us to calculate the remaining characteristics of the meteoroid $\omega_{m}, r_{m}$, from observing the frequencies of the "wobbling" and brightness variations. Thus, two-side observations make it possible to determine all the characteristics of the meteoroid if we measure the frequencies of $\Theta_{c}$ and $\Theta_{m}$.

First, we need to determine the parameter $\omega_{m}$ - the frequency of the angular rotation of the meteoroid. What makes a meteor spin? A meteoroid can be considered as an air turbine that converts the energy of the airflow into rotational energy. The aerodynamic quality of a meteoroid depends on the ratio of lift (elevator) to dynamic drag. A conventional thin flat plate is known to be an effective lifting surface. It can be assumed that the meteoroid also has the necessary lifting force. It is important to note that these aerodynamic qualities are preserved mainly during supersonic and even hypersonic motion of a meteoroid [10].

The energy of rotation $E$ of the object is equal to

$$
E=\frac{1}{2} I \omega_{m}^{2},
$$

where $I$ is the moment of inertia around the axis of rotation. The area of the turbine is given by $S$, and the power (rate of work done) of the gas stream is

$$
P=\frac{d E}{d t}=F_{m} \cdot v .
$$

The power that can be extracted from the gas stream is determined by the following expression [11]

$$
P=\frac{C_{P}}{2} \rho S v^{3} .
$$

Here $C_{P}$ is the "power coefficient", dimensionless ratio of the extractable power $P$ to the kinetic power available in the gas stream.

We can obtain an estimate the angular frequency of the rotation of the meteoroid as

$$
\omega_{m}=\sqrt{\frac{C_{P}}{2} \rho S v^{3} / I \cdot T} .
$$

$T$ is the time span. The power coefficient $C_{P}$ is described by Betz's law that indicates the power that can be extracted from the wind, independent of the design of a wind turbine in open flow as a function of $\left(r_{m} \cdot \omega_{m}\right) / v$ [11]. It has a maximum value $C_{P} \max =16 / 27=0.593$ when $\left(r_{m} \cdot \omega_{m}\right) / v=1 / 3 C_{P}$ tends to zero when $\left(r_{m} \cdot \omega_{m}\right) / v$ tends to unity. It is easy to see that in this case, the meteoroid surface rotation velocity coincides with the gas flow rate $\left(r_{m} \cdot \omega_{m}\right)=v$. As noted by Prandtl [8], "the velocity of a stream $v$ cannot be mixed with the surface velocity of a rotating body. The relation between these velocities is not predetermined and is not simple at all; so far it has to be found from experience."

Most meteoroids end with an explosion. As the meteoroid moves the atmospheric density increases and the stagnation pressure at the meteoroid, $p_{s}=\rho v^{2}$ rises. Eventually, this exceeds the strength of the meteoroid, and it begins to break up. Destruction of a meteoroid occurs also when the centrifugal force arising from rotation becomes equal to the normal force determining the tensile strength of the material of which the meteor consists. Tensile strength is determined by Young's modulus

$$
Y=\frac{F_{n} / S}{\Delta l / l},
$$

where $Y$ is Young's modulus, $F_{n}$ - normal force, $S$ - surface area, $\Delta l / l-$ change in length and length during deformation. Assuming $\Delta l / l \simeq 1$ and, equating the forces, we obtain the fracture condition for the stagnation pressure and the centrifugal destruction

$$
\begin{gathered}
Y=\rho v^{2}, \\
Y=\rho_{m} \cdot \omega_{m}^{2} \cdot r^{2}=\rho_{m} \cdot v_{m}^{2},
\end{gathered}
$$

where $\rho_{m}$ is the density of the meteoroid, $v_{m}$ - rotation speed on the meteoroid surface. 
The Young's modulus of stone meteorites varies from 5.2 to $8,7 \cdot 10^{10} \mathrm{~Pa}$, which corresponds to the elasticity (deformation characteristics) of the Earth's main rocks [13]. Assuming Young's modulus $Y=50$ $\mathrm{GPa}$ and $\rho_{m}=5 \mathrm{~g} / \mathrm{cm}^{3}$ for meteoroid of mineral composition, we obtain the boundary value of the meteoroid surface rotation speed $v_{m} \approx 3 \mathrm{~km} / \mathrm{s}$. When a meteoroid spins to a boundary speed on the surface of about three kilometers per second, which is often comparable to the speed of a meteoroid, it explodes.

Laboratory studies have shown that the tensile strength for different samples of stone meteorites varies in the range of 20 to $200 \mathrm{MPa}$ [13]. Thus, the value of the velocity $v_{m} \approx 3 \mathrm{~km} / \mathrm{s}$ can be considered as a conditional value.

\section{MODEL OF THE ABLATION FOR ESTIMATION THE METEOROID CHARACTERISTICS}

We use the classical meteor ablation theory $[12,14]$. This model traces the variation of the meteoroid velocity, deceleration, mass and visual radiation with time. By varying the appropriate model parameters such as initial conditions, the effect of them can be readily evaluated. The meteoroid momentum is decreased through collisions with air molecules. The momentum transfer can be quantified with the help of Newton's second law (3). A second equation, the differential mass equation, is derived by assuming that the rate of loss of mass is proportional to the kinetic energy transferred to the mass of air intercepted by the meteoroid:

$$
\frac{d m}{d t}=\frac{\Lambda A \rho v^{3} m^{2 / 3}}{2 \xi \rho_{m}^{2 / 3}},
$$

where $\Lambda$ is the heat transfer coefficient, $\xi$ is the heat of ablation of the meteoroid.

The visual power radiated by the meteoroid is given by

$$
I=0.5 T_{I} \frac{d m}{d t} v^{2},
$$

where $T_{I}$ is the luminous radiation efficiency. This may be converted into a rough apparent visual magnitude for a ground-based observer through the empirical relation

$$
V=6.8-1.086 \ln I \text {. }
$$

The table below lists typical initial values for the above parameters used in the computer implementation of the model.

$\xi$ - meteoroid heat of ablation $\left(3 \cdot 10^{6} \mathrm{~J} \mathrm{~kg}^{-1}\right)$;

$\Lambda$ - heat transfer coefficient $(0.15)$;

$T_{I}-$ luminous efficiency $1 \cdot 10^{-3}$.

The model use for the density of the Earth's atmosphere a simple exponential expression of the form $\rho=\rho_{0} \cdot \exp (-h / H)$.

The model described by the above equations can be implemented by the Impact $4 \mathrm{~A}$ Software [12]. The numerical integration of the differential equations was performed using a Runge-Kutta 4 integrator. This was found to be stable at time steps of $0.001 \mathrm{~s}$.

\section{THEORY AND OBSERVATIONS}

How does the above theory correspond to reality? Consider the light curve reproduced above (Fig. 2, 3). The ablation of a $0.45 \mathrm{~kg}$ solid meteoroid with an initial velocity of $40 \mathrm{~km} / \mathrm{s}$ was simulated using the Impact $4 \mathrm{~A}$ Software considered above [12]. The meteoroid reaches the height of $82 \mathrm{~km}$ with only $2.2 \%$ of its starting mass and exploded due to dynamical or centrifugal destruction depending of $C_{P}$. We show that "tuning technique" in combination with a simulation model of intrusion allows determining the meteor characteristics during one-side observations.

Fig. 5 shows the speed of the meteoroid depending on the height, the speed of rotation on the surface and the critical speed of dynamic destruction. It is easy to see that the limit of dynamic fracture is not reached. This means that the destruction of the meteoroid has a centrifugal character. The meteoroid reached a critical value of the speed of rotation on the surface of about $3 \mathrm{~km} / \mathrm{s}$ at an altitude of about $82.2 \mathrm{~km}$ in a time of about $3 \mathrm{sec}$. At this moment, a meteoroid exploded and destroyed. Note that variations in the value of $C_{P}$, which determines the boundary rotation velocity on the meteoroid surface in the range of $1-3 \mathrm{~km} / \mathrm{s}$, insignificantly change the estimate the meteoroid explosion height, within $82-83 \mathrm{~km}$.

In Fig. 7, we can see that the brightness of the meteoroid reached $V=-2$ magnitudes. In this case, the residual mass was about 10 grams. Thus, ablation "ate" $98 \%$ of the initial mass of the meteoroid.

Fig. 6 plays a crucial role in our work. The figure shows the values of the frequencies $f_{c}, f_{m}$ depending on the height. By varying the initial parameters of the model, the primary mass and speed of the meteoroid at the boundary of the Earth's atmosphere, we find the height at which the frequency ratio $f_{c} / f_{m}$ coincides with the value found from the measurements. In the case of basic observations, when the height and speed of the meteoroid are known, as noted above, all the characteristics of the meteoroid can be calculated using formulas (7), (12). Moreover, the calculation of the characteristics of the meteoroid does not require simulation. 


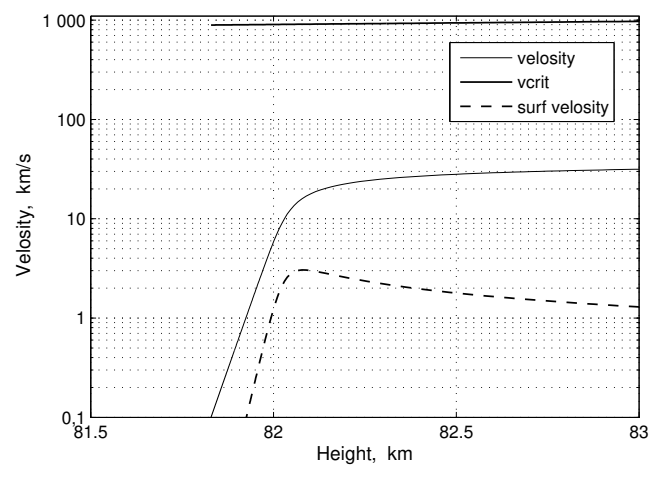

Fig. 5. The speed of the meteoroid depending on the height, the speed of rotation on the surface and the critical speed of dynamic destruction

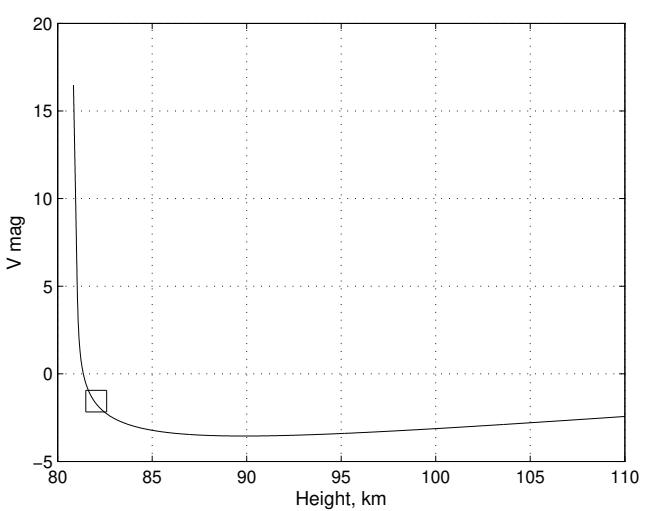

Fig. 7. The brightness of the meteoroid depending on the height

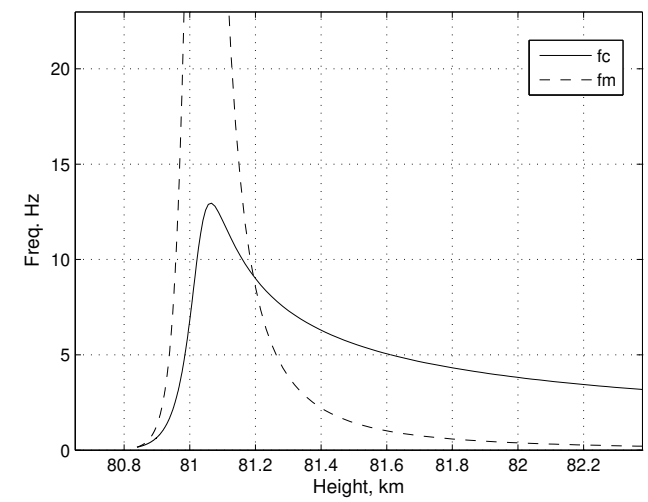

Fig. 6. The values of the frequencies $f_{c}, f_{m}$ depending on the height

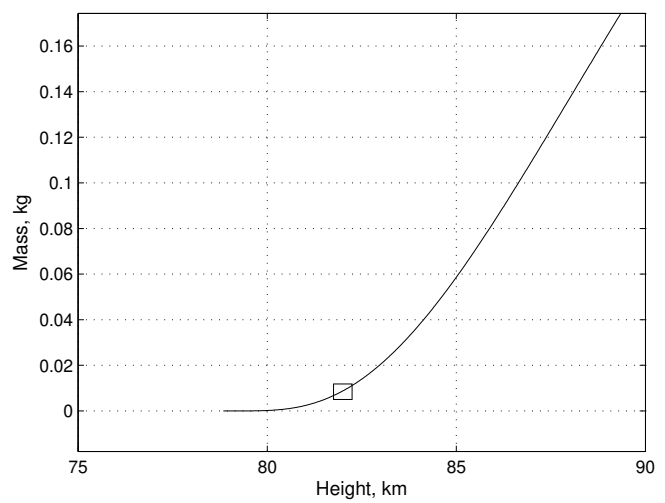

Fig. 8. The value of the meteoroid mass depending on the height

In the case of one-side observations, we construct a grid of models on the plane of the primary "mass-speed" meteoroid. Thus, as a result of modelling, we find the height at which the frequency ratio $f_{c} / f_{m}$ coincides with the value found from measurements for exploding meteoroid.

Thus, we can conclude:

- "Tuning technique" in combination with a simulation model of intrusion allows determining the meteor characteristics during one-side observations.

- It was found that the progenitor of the meteor is an object weighing $450 \mathrm{~g}$ at a speed of $40 \mathrm{~km} / \mathrm{s}$, travelled in $3 \mathrm{sec}$ at an altitude of about $82 \mathrm{~km}$ with a residual mass of about $10 \mathrm{~g}$ and a residual speed of about $20 \mathrm{~km} / \mathrm{s}$.

- As can be seen from Figs. 3 and 4 , the amplitude of the brightness fluctuations is about 0.1 magnitude, the amplitude of the wobbling is about 4 arc seconds. Hence, it is possible to calculate that the radius of the helical path at the height of the meteor explosion is about 1.5 meters.

\section{RESULTS AND CONCLUSIONS}

This work is devoted to determining the meteor characteristics during one-side observations. Photometry of the meteor track indicates brightness variations, as well as fluctuations in the trajectory transverse to the direction of motion. Spectroscopic analysis of a meteor of about -2 visual magnitudes is presented on the basis of a spectrogram with absolute line intensities.

Photometry of the meteor made it possible to determine the oscillation frequency estimated on a time scale of about half of the sec, as well as the transverse oscillations of the trajectory. We use "tuning technique" in combination with a simulation model of intrusion for determining the meteor characteristics. It was found that the progenitor of the meteor is an object weighing $450 \mathrm{~g}$ at a speed of $40 \mathrm{~km} / \mathrm{s}$, The meteoroid reached a critical value of the speed of rotation on the surface of about $3 \mathrm{~km} / \mathrm{s}$ at an altitude of about $82 \mathrm{~km}$ in a time of about $3 \mathrm{sec}$ with a residual mass of about $10 \mathrm{~g}$, and a residual speed of about $20 \mathrm{~km} / \mathrm{s}$. At this moment, a meteoroid exploded and destroyed. The radius of the helical path at the height of the meteor explosion is about 1.5 meters. 
1. Petrov V.N. Some problems of the physics of meteors // Uspekhi Fizicheskikh Nauk. - 1939. - XXII, 4. P.449-463.

2. Lindemann F.A., Dobson G.N. Theory of Meteors // Proc. Roy. Astr. Soc. - 1922. - A102. - P.717.

3. Collins G.S., Melosh H.J., Marcus R.A. Earth Impact Effects Program: A Web-based computer program for calculating the regional environmental consequences of a meteoroid impact on Earth // Meteoritics \& Planetary Science. 2005. - Vol. 40, No. 6. - P.817-840. https://doi.org/10.1111/j.1945-5100.2005.tb00157.x

4. Popova O.P., Sidneva S.N., Strelkov A.S., Shuvalov V.V. Formation of Disturbed Area Around Fast Meteor Body // Proc. of the Meteoroid 2001 Conf. 6-10 August 2001 (ESA SP-495, November 2001). - P.237-245.

5. Mehta C., Perez A., Thompson G., Pasek M.A. Caveats to Exogenous Organic Delivery from Ablation, Dilution, and Thermal Degradation // Life. - 2018. - Vol. 8. - P.13. https://doi.org/10.3390/life8020013

6. McKinley D. Meteor Science and Engineering. - Toronto: McGraw-Hill, 1961.

7. Ceplecha Z., Borovicka J., Elford G., et al. Meteor phenomena and bodies // Space Sci. Rev. - 1998. - Vol. 84. P.327-471.

8. Prandtl L. Magnus effect and a wind ship // Uspekhi Fizicheskikh Nauk. - 1925. - Vol. V, No. 1-2. - P.1-27.

9. Anderson J.D. Fundamentals of Aerodynamics: Second Edition. - McGraw-Hill, Inc., 1991.

10. Küchemann D. Störungsbewegungen in einer Gasströmung mit Grenzschicht // Zeitschrift für Angewandte Mathematik und Mechanik. - 1938. - Band 18, Heft 4. - P.207-222. https://doi.org/10.1002/zamm.19380180402

11. Betz A. Introduction to the Theory of Flow Machines. - Oxford: Pergamon Press, 1966.

12. Downs B. Impact 4A Software. Meteor Atmospheric Flight, 1998. https://www.spaceacademy.net.au/watch/debris/metflite.htm

13. Slyuta E.N. Physical and Mechanical Properties of Stone Meteorites // Astronomical Bulletin. - 2017. - Vol. 51. No. 1. - P.72-95.

14. Campbell-Brown M.D., Koschny D. Model of the ablation of faint meteors // Astron. and Astrophys. - 2004. Vol. 418. - P.751-758. https://doi.org/10.1051/0004-6361:20041001-1

\section{Фізика космічних вторгнень. І. Особливості траєкторій}

Жиляєв Б.Ю., Відьмаченко А.П., Стеклов О.Ф., Похвала С.М., Верлюк І.А.

Головна астрономічна обсерваторія НАН України, 03143, м. Київ, вул. Академіка Заболотного, 27

У даній статті представлені теоретичні розробки деяких питань фізики космічних вторгнень. Ми повідомляємо про відкриття нового ефекту - зміни яскравості і “бовтанки” в сліді метеора. Частота варіацій яскравості $f_{c}$ i коливання $f_{m}$ траєкторії, які можуть бути виміряні, $є$ важливими інформаційними параметрами, які дозволяють нам отримувати оцінки всіх характеристик метеора, якщо його висота і швидкість відомі. Основні двосторонні спостереження автоматично визначають як висоту, так і швидкість вторгнення. Ми пропонуємо нову «техніку налаштування», яка дозволяє визначати метеорні характеристики при односторонніх спостереженнях. Суть нової техніки полягає в точному налаштування початкових параметрів імітаційної моделі вторгнення, поки розрахункові та виміряні частоти $f_{c}$ i $f_{m}$ не співпадуть. Ми виявили, що обертання грає важливу роль в динаміці метеорів; зокрема, вони можуть вибухнути через відцентрові сили, які перевищують міцність матеріалу. У разі односторонніх спостережень ми будуємо сітку моделей вторгнень, використовуючи програму Impact 4A на площині первинна “маса-швидкість" метеороїда. В результаті моделювання ми знаходимо висоту, на якій частотне відношення $f_{c} / f_{m}$ збігається зі значенням, отриманим з вимірів для метеороїда, що вибухає. У статті описуються характеристики космічного вторгнення метеора, зображення якого отримано в Києві 12 серпня 2019 р. 22:52:57 UT. Амплітуда коливань яскравості становила близько 0,1 зоряної величини, амплітуда бовтанки - близько 4 кутових секунд. Використовуючи програму Impact 4A, швидкість перед входженням в атмосферу оцінювалася приблизно у 40 км/с; маса метеорита оцінювалася приблизно в 0,45 кг. Цей метеороїд досяг максимуму блиску на висоті 82,2 км. Ми знайшли оцінку залишкової маси близько 10 грам і залишкової швидкості близько $20 \mathrm{kм} / \mathrm{c}$. Ми виявили, що радіус спіральної траєкторії метеора на цій висоті становив близько 1,5 м. На цій висоті метеороїд досяг критичного значення швидкості обертання на своїй поверхні. У цей момент метеороїд вибухнув і зруйнувався.

Ключові слова: космічні вторгнення; методи: спостереження; методи обробки: фотометрія; об’єкти: метеори.

\section{Физика космических вторжений. І. Особенности траекторий}

Жиляев Б.Е., Видьмаченко А.П., Стеклов А.Ф., Похвала С.М., Верлюк И.А.

Главная астрономическая обсерватория НАН Украины, 03143, г. Киев, ул. Академика Заболотного, 27

В данной статье представлены теоретические разработки некоторых вопросов физики космических вторжений. Мы сообщаем об открытии нового эффекта - изменения яркости и «болтанки» в следе метеора. Частота вариаций яркости $f_{c}$ и колебания $f_{m}$ траектории, которые могут быть измерены, являются важными информационными параметрами, которые позволяют нам получать оценки всех характеристик метеора, если его высота и скорость известны. Основные двухсторонние наблюдения автоматически определяют как высоту, так и скорость вторжения. Мы предлагаем новую «технику настройки», которая позволяет определять метеорные характеристики при односторонних наблюдениях. Суть новой техники заключается в точной настройке начальных параметров имитационной модели вторжения, пока расчетные и измеренные частоты $f_{c}$ и $f_{m}$ не совпадут. Мы обнаружили, что вращение играет важную роль в динамике метеоров; в частности, они могут взорваться из-за центробежных сил, которые превышают прочность материала. В случае односторонних наблюдений мы строим сетку моделей вторжений, используя программу Impact 4A на плоскости первичная “масса-скорость” метеороида. В результате моделирования мы находим высоту, 
на которой частотное отношение $f_{c} / f_{m}$ совпадает со значением, полученным из измерений для взрывающегося метеороида. В статье описываются характеристики космического вторжения метеора, наблюдаемого в Киеве 12 августа 2019 г., 22:52:57 UT. Амплитуда колебаний яркости была найдена около 0,1 звездной величины; амплитуда болтанки составляла около 4 угловых секунд. Используя программу Impact 4A, скорость перед атмосферой оценивалась примерно в $40 \mathrm{~km} / \mathrm{c}$; масса метеора оценивалась примерно в 0,45 кг. Этот метеороид достиг максимума блеска на высоте 82,2 км. Мы находим оценку остаточной массы в 10 грамм и остаточной скорости - около 20 км/с. Мы обнаружили, что радиус спиральной траектории метеора на этой высоте составляет около 1,5 м. Метеороид достиг критического значения скорости вращения на своей поверхности. В этот момент метеороид взорвался и разрушился.

Ключевые слова: космические вторжения; методы: наблюдения; методы обработки: фотометрия; объекты: метеоры.

Надійшла до редакції / Received

Прийнята до друку / Accepted

31.07 .2020 